\title{
Murine Skin Carcinogenesis and the Role of Immune System Dysregulation in the Tumorigenicity of 2-Ethylhexyl Acrylate
}

\author{
Craig A. Elmetsa, b, c Nabiha Yusufa, b, c \\ a Department of Dermatology, University of Alabama at Birmingham, Birmingham, AL, USA; \\ ${ }^{b} O^{\prime}$ Neal Comprehensive Cancer Center, University of Alabama at Birmingham, Birmingham, \\ AL, USA; ${ }^{c}$ Veteran Affairs Medical Center, Birmingham, AL, USA
}

\begin{abstract}
What Is It about?
2-Ethylhexyl acrylate (2-EHA) is used as a co-monomer in the production of polymer resins for various products. There are no reports of human cancers caused by 2-EHA exposure, but it has been reported to cause cancer in a mouse strain with a dysregulated immune system. We reviewed the literature on the preclinical effects of acrylates on skin carcinogenesis and concluded that to date 2-EHA has not convincingly been demonstrated to have skin carcinogenic activity. Mouse models without a dysregulated immune system that mimic human melanoma and non-melanoma skin cancer are needed to assess the carcinogenic effects of 2-EHA.
\end{abstract}

\section{Keywords}

2-Ethylhexyl acrylate $\cdot$ Skin cancer $\cdot$ Toxicity $\cdot$ Mouse models

\begin{abstract}
Some chemicals act as human carcinogens in various organ systems including the skin. Mice have been an ideal model to study a wide variety of chemical carcinogens because the pathogenesis in that species often mirrors that in humans. However, different mouse strains vary in their susceptibility to these agents. Thus, reliance on a single strain may lead to inaccurate findings. 2-Ethylhexyl acrylate (2-EHA) is an acrylate used as a co-monomer in the production of polymer resins for adhesives, latex paints, cross-linking agents, finishes for textiles and leather, and paper coatings. Monomer exposure may occur in occupational settings where it is produced or used; the only exposure that may occur to consumers or construction personnel is trace amounts in the final polymer product. There are no reports of cancer in humans caused by exposure to 2-EHA. However, 2-EHA has been reported to cause cancer in one strain of mice. This is an important issue since recommendations about its safety in humans depend, in part, on information derived from animal studies. We reviewed the literature on the preclinical effects of acrylates on skin carcinogenesis in $\mathrm{C} 3 \mathrm{H} / \mathrm{HeJ}$ mice, which can be crit-
\end{abstract}


icized because of peculiarities in the immunological composition of that strain, the lack of rigorous histopathologic characterization of tumors that developed, the high doses of 2-EHA that were used for evaluation, and the lack of reproducibility in a second strain of mice. The $\mathrm{C} 3 \mathrm{H} / \mathrm{HeJ}$ mouse model is not ideal as it has a mutation in Toll-like receptor 4 (TLR4) that impairs its innate and adaptive immune responses. Inconsistencies in the histological evaluation of tumors induced in $\mathrm{C} 3 \mathrm{H} / \mathrm{HeJ}$ mice provide further evidence that the tumorigenic effect of 2-EHA was strain specific, a result of chronic inflammation during the promotion stage and/ or a skewed immune response caused by the TLR4 mutation. In conclusion, 2-EHA has not convincingly been demonstrated to have skin carcinogenic activity to date. More relevant mouse models that mimic human squamous cell carcinoma, basal cell carcinoma, and melanoma with amounts that do not exceed a maximum tolerated dose are needed to assess the carcinogenic effects of 2-EHA.

\section{Introduction}

Non-melanoma skin cancers (NMSCs) are an important health care problem. In the United States alone, over 5 million new NMSCs are diagnosed each year [1, 2]. While the majority are caused by excessive exposure to ultraviolet (UV) radiation, a significant percentage are produced by other factors, such as human papilloma virus, X-radiation, ongoing inflammatory processes (such as those following chronic skin damage or in certain cutaneous diseases), and chemical exposure [3]. Mortality due to cutaneous squamous cell carcinoma (SCC) and basal cell carcinoma (BCC) is low relative to other malignancies, but the overall socioeconomic burden of NMSC is high [1,2]. Because of this, there has been an ongoing attempt to prevent skin cancer and to identify chemicals that may have carcinogenic activity.

Based on studies in animal models, it has been established that skin cancers develop through an orderly sequence of events in which molecular and biochemical changes occur in keratinocytes over long periods of time [4, 5]. In the first stage, termed initiation, mutations in keratinocytes are produced following exposure to a mutagenic event (e.g., mutagenic chemicals, UV light, X-radiation, viruses, or reactive oxygen species). Largely under control of the p53 protein, mutant keratinocytes undergo diminished proliferation and fail to progress through the cell cycle so that the damage can be repaired. If the damage is too extensive, then the p53 protein redirects the cell to undergo death by apoptosis. In situations in which p53 is mutated, this repair process and/or cell death does not occur. During the second stage, called promotion, unrepaired, mutant keratinocytes become targets for repeated exposure to tumor promoters. Mutant keratinocytes that have not been repaired and have not undergone apo ptosis often have a selective proliferative advantage over non-mutated keratinocytes. Thus, the number of mutant keratinocytes increases. Eventually, this results in clinically and histologically apparent premalignant keratoses. In the third stage called progression, some of the premalignant keratoses acquire additional genetic and biochemical changes that allow them to become invasive SCCs.

\section{The Immune System and Skin Cancer Development}

Cutaneous SCCs are highly immunogenic tumors, and there is considerable evidence that the host immune system contributes in a major way to prevent their development and growth. For example, in contrast to many of the cancers that arise in other organs, these tumors develop

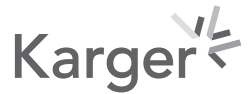


gradually, rarely metastasize, and are associated with a chronic inflammatory infiltrate [6]. Cutaneous SCCs develop from premalignant keratoses. Over 25\% of premalignant keratoses undergo spontaneous regression, presumably by activation of cell-mediated immune defenses directed at antigens expressed by the pre-neoplastic cells [7]. Cutaneous SCCs and BCCs are more frequent in immunosuppressed individuals. Over $50 \%$ of renal transplant recipients on long-term immunosuppressive therapy have been diagnosed with at least one NMSC [8-10]. The predisposition to skin cancer is not restricted to transplant patients. Lymphoma and chronic lymphocytic leukemia patients, who also have subtle defects in cellular immune function, have an increased incidence of BCCs and SCCs [11, 12]. Immunologic abnormalities have been detected in skin cancer patients who are otherwise normal. These patients have suppressed immune responses to skin test antigens, which are mediated by Tlymphocytes [13, 14], and decreased sensitization rates to the contact allergen dinitrochlorobenzene (DNCB). Allergic contact dermatitis is an immune response mediated by $\mathrm{T}$ lymphocytes $[13,14]$. In addition, when the inflammatory infiltrates around BCCs are examined, a disproportionate number of regulatory $\mathrm{T}$ cells that suppress anti-tumor immune responses are present [15]. Compared to SCCs in non-immunosuppressed hosts, cutaneous infiltrates around SCCs of organ transplant recipients (OTRs) have significantly fewer CD8+ T cells and a higher Foxp3+:CD8+ ratio [16]. Tumors in OTRs also have decreased CD4+ Th1 cells, which secrete IFN- $\gamma$, a cytokine important in the immune response to cutaneous SCCs in animal models and in humans. Infiltrates around SCCs in OTRs also have greater numbers of T cells producing IL-22 (i.e., Tc22) than SCCs in non-OTRs [16]. IL-22-producing T cells (Th22 or Tc22) support keratinocyte proliferation and potentially accelerate tumor growth. This sets the stage for sustained accelerated tumor growth in transplant patients with potentially catastrophic results.

Experimental studies in mice support the concept that vigorous host cell-mediated immune responses have a protective effect on skin cancer development. These studies were first conducted with UV-induced skin tumorigenesis [17]. Mice that were chronically exposed to UV radiation, like humans, develop UV-induced SCCs [18]. In a classic series of experiments, when these tumors were removed and transplanted to the skin of genetically identical recipient mice, the tumors initially engrafted, but eventually regressed due to a vigorous host cell-mediated immune response against the tumor [17]. However, when the same tumors were transplanted to genetically identical recipients that had received sub-carcinogenic doses of UV radiation, the tumors grew progressively, were not immunologically eradicated, and ultimately killed their hosts. Based on these experiments, it is possible to conclude that UV radiation impairs activation of host immune responses, the purpose of which is to destroy mutant epidermal cells before they can become malignant tumors.

Similar findings with respect to immunological influences on skin carcinogenesis have been observed with carcinogenic chemicals [19-22]. When cutaneous cell-mediated immunological function to the carcinogenic polyaromatic hydrocarbon (PAH) dimethylbenz(a)anthracene (DMBA) was investigated in congenic strains of mice, those strains that were able to mount a cell-mediated response to DMBA were found to have fewer DMBA-DNA adducts than congenic strains of mice that failed to develop an immune response to that chemical [19]. When subjected to a DMBA initiation, phorbol 12-tetradecanoate 13-acetate (TPA)-promotion skin tumorigenesis protocol, mice that did develop cell-mediated immunity to DMBA were found to have significantly fewer tumors than congenic strains that did not. Definitive evidence of the protective role of cell-mediated immunity was derived from studies in which mice were treated in such a way that they developed antigen-specific immunological tolerance to DMBA. Immunologically tolerant animals that failed to develop cell-mediated immunity to DMBA developed more tumors than those that maintained an immune response to DMBA [21]. These observations provide definitive evidence that cell-mediated immunity to chemical carcinogens serves to protect individuals by removing mutant cells before they can evolve into clinically apparent neoplasms.

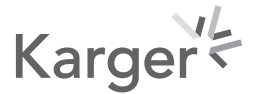


Table 1. Animal criteria for skin carcinogenesis regulatory testing

\begin{tabular}{|c|c|c|}
\hline & C3H/HeJ Mice & NMRI Mice \\
\hline $\begin{array}{l}\text { The mouse strain should not develop spontaneous tumors as } \\
\text { this may compromise the study }\end{array}$ & $\begin{array}{l}\text { Increased incidence } \\
\text { of hepatomas }\end{array}$ & $\begin{array}{l}\text { Low frequency of } \\
\text { spontaneous } \\
\text { tumors }\end{array}$ \\
\hline $\begin{array}{l}\text { The mouse strain should be able to survive for the entire course of } \\
\text { the experiment, and it should have an adequate historical database }\end{array}$ & $\begin{array}{l}\text { Survives, historic } \\
\text { control data } \\
\text { available }\end{array}$ & $\begin{array}{l}\text { Survives, historic } \\
\text { control data } \\
\text { available }\end{array}$ \\
\hline $\begin{array}{l}\text { At the dose employed for testing, the skin should be resistant } \\
\text { to irritation }\end{array}$ & $\begin{array}{l}\text { Irritant at the } \\
\text { doses employed }\end{array}$ & $\begin{array}{l}\text { Nonirritant at the } \\
\text { doses employed }\end{array}$ \\
\hline $\begin{array}{l}\text { The strain should be available, breeder specific, and genetically } \\
\text { stable }\end{array}$ & Available & Available \\
\hline $\begin{array}{l}\text { All facets of both the innate and adaptive immune system should } \\
\text { be intact unless anti-tumor immunity is being evaluated }\end{array}$ & $\begin{array}{l}\text { Aberrant innate and } \\
\text { adaptive immunity }\end{array}$ & $\begin{array}{l}\text { Normal innate and } \\
\text { adaptive immunity }\end{array}$ \\
\hline
\end{tabular}

\section{Chemically Induced Skin Carcinogenesis}

Knowledge that chemicals can cause skin cancer dates back to the original observations of Sir Percival Pott in 1775, when he described the predisposition of chimney sweeps to scrotal cancer [23]. The soot to which these workers were exposed contained large amounts of carcinogenic PAHs.

Mice have been used extensively for evaluation of known carcinogens, including X-radiation, ultraviolet radiation, and carcinogenic chemicals. They are susceptible to cutaneous tumor induction, and the tumors that arise can be easily identified visually, thus minimizing the use of invasive processes for tumor monitoring. Many features also make mice an excellent experimental model for carcinogenicity testing for regulatory agencies and for mechanistic studies. They are easy to maintain; have a relatively short life span, and there are a variety of well-characterized strains for carcinogenicity testing [24]. Similar to humans, carcinogen-induced genetic changes in mouse models and sustained inflammation lead to tumor progression [25].

It is important to emphasize that in order to be eligible for use in regulatory or mechanistic skin carcinogenesis experiments, several criteria need to be met (Table 1) [26-28].

Investigation in mice has enhanced our understanding of the pathogenesis of epithelial cancers [29]. The mouse genome has been fully sequenced and annotated; absorption/pharmacokinetic data are available for a variety of chemicals; and there are a wide variety of genetic and molecular tools to modify their pathophysiology [26-28]. Mouse 2-stage skin carcinogenesis has been used extensively to study tumor latency, multistaging, and progression of skin cancer, and provides the mechanistic basis for the way in which chemicals cause skin cancer [29]. In this model, a single dose of the mutagenic chemical carcinogen is used for tumor initiation. This single irreversible event is enhanced by application of a tumor promoter like TPA. Thus, the initiation and promotion phases can be evaluated separately [4], which is a distinct advantage for the study of processes involved in different phases of tumor development. This system also provides reliable results in studies on chemoprevention and cytostatics [30]. The molecular mechanisms that underlie the development of skin tumors have been studied using this model [31, 32].

Different mouse strains vary in their susceptibility to cancer-causing agents. Animal models with natural or engineered phenotypic and genotypic characteristics have provided immunologists and cancer biologists with the opportunity to carefully evaluate the patho- 
Table 2. Differences between $\mathrm{C} 3 \mathrm{H} / \mathrm{HeN}$ and $\mathrm{C} 3 \mathrm{H} / \mathrm{HeJ}$ Mice

\begin{tabular}{|c|c|c|}
\hline & $\mathrm{C} 3 \mathrm{H} / \mathrm{HeN}$ & $\mathrm{C} 3 \mathrm{H} / \mathrm{HeJ}$ \\
\hline TLR4 gene & Normal & Mutated \\
\hline Response to LPS & Normal & Deficient \\
\hline $\begin{array}{l}\text { Response to other stimuli (Taxol, fibronectin, heat } \\
\text { shock protein } 60 \text { ) }\end{array}$ & Normal & Deficient \\
\hline Activation of MyD88 & Normal & Deficient \\
\hline $\begin{array}{l}\text { Biological effects } \\
\text { Macrophage responsiveness }\end{array}$ & & \\
\hline $\begin{array}{l}\text { Lysosomal enzyme deficiency } \\
\text { Neuroimmune processes } \\
\text { Phagocytic Kupffer cell number }\end{array}$ & Normal & Deficient \\
\hline Cutaneous T-cell mediated immunity & IFN- $\gamma$ mediated & IL-17 and IFN- $\gamma$ mediated \\
\hline Serum IL-12 following dermal application of DMBA & Normal & Normal \\
\hline Serum IL-23 following dermal application of DMBA & Normal & Diminished \\
\hline Chemical carcinogenesis & Fewer tumors than $\mathrm{C} 3 \mathrm{H} / \mathrm{HeJ}$ & More tumors than $\mathrm{C} 3 \mathrm{H} / \mathrm{HeN}$ \\
\hline
\end{tabular}

genesis and immunopathogenesis of skin tumor development [33]. For example, PAH-induced skin carcinogenesis has been exploited to carefully define the different stages that lead to clinically apparent cutaneous tumors [34-36].

By targeting the genetic modifications in cutaneous tissue, one can study gene overexpression or deletion in specific skin compartments, mimicking spontaneous genetic events that occur in epithelial carcinogenesis [37]. For example, it was discovered that PAH skin carcinogenesis can only be tested in aryl hydrocarbon (Ah) receptor-positive strains of mice, because PAHs require metabolism by cytochrome $\mathrm{P}_{450}$-dependent enzymes, which are induced by activation of the Ah receptor. There are a number of Ah receptor-negative strains of mice, which, when tested, do not develop skin cancers to PAHs but can do so to other cancer-causing agents.

\section{C3H/HeN and C3H/HeJ Mouse Models}

The $\mathrm{C} 3 \mathrm{H} / \mathrm{HeN}$ mouse strain was generated in 1920 by crossing a BAGG albino female with a DBA male [38, 39]. This mouse strain was used to study breast cancer because of its high incidence of developing mammary tumors due to the fact that these mice contained a genetically transmitted proviral genome for the mouse mammary tumor virus (MMTV). Additionally, this mouse strain is able to transmit the virus to their offspring in milk [40]. MMTV activates vitamin D-mediated signal transduction pathways that are important for carcinogenesis [40], which may complicate interpretation of results of earlier studies. The stock of these mice was transferred to the National Institutes of Health (NIH) in 1951. However, the current strain is not a carrier of MMTV anymore [40]. C3H/HeN mice are homozygous for the Pde $6 \mathrm{~b}^{\text {rd1 }}$ allele and are susceptible to early retinal degeneration leading to blindness at a very early age [41]. These mice have a high incidence of hepatoma but are resistant to atherosclerosis even after consumption of an atherogenic diet [42, 43].

The $\mathrm{C} 3 \mathrm{H} / \mathrm{HeJ}$ strain arose from $\mathrm{C} 3 \mathrm{H} / \mathrm{HeN}$ mice through a natural mutation in the Toll-like receptor 4 (TLR4) gene [41]. This is the only known difference between both strains, and comparing the 2 strains has been a powerful method of investigating the role of TLR4 in a variety of diseases [44]. Importantly, the 2 strains respond differently to lipopolysaccharide (LPS), the bacterial endotoxin present in the cell wall of gram-negative bacteria (Table 2) [45]. Release of LPS is responsible for septic shock in gram-negative bacterial infections [45]. C3H/HeN mice are Tlr4 $4^{\text {lps-n }}$ (TLR4, normal LPS response) and respond normally to LPS. On 
the other hand, $\mathrm{C} 3 \mathrm{H} / \mathrm{HeJ}$ mice have a defective response to LPS (Tlr $4{ }^{\text {lps-d }}$ ) that makes them resistant to endotoxic shock. In addition to LPS, TLR4 also recognizes a variety of nonbacterial agonists such as taxol [46], fibronectin [47, 48], and heat shock protein 60 [49].

As a result of the TLR4 mutation, the $\mathrm{C} 3 \mathrm{H} / \mathrm{HeJ}$ mouse strain has an aberrant immune system with dysregulated immune and inflammatory pathways. $\mathrm{C} 3 \mathrm{H} / \mathrm{HeJ}$ mice exhibit defective macrophage responsiveness, lysosomal enzyme deficiency, a paucity of phagocytic Kupffer cells, and an atypical T-cell response [50-52]. These immunological abnormalities in TLR4 signaling in $\mathrm{C} 3 \mathrm{H} / \mathrm{HeJ}$ mice impair their ability to mount a normal Th1 response [53], which is a critical component of the host immune defense against cancer. TLR4 deficiency has also been reported to affect olfactory-based spatial learning activity of neonatal mice after developmental exposure to secondary organic aerosol from diesel exhaust, indicating the involvement of the neuroimmune system in this process [54]. A common missense mutation in TLR4, Asp ${ }^{299} \mathrm{Gly}$, is associated with LPS hyporesponsiveness in humans. Thus, changes in the TLR4 gene sequence can alter the ability of the host to respond to environmental stressors [55]. A defect in TLR4 signaling diverts the immune response to carcinogenic chemicals from one that is mediated by IFN- $\gamma$-producing T cells (Th1) to one in which IL-17-producing T cells (Th17) predominate. IL-17 facilitates the influx of myeloid-derived suppressor macrophages which in turn diminishes the host immune response [22].

\section{C3H Mouse Models and 2-Stage Chemical Carcinogenesis}

The $\mathrm{C} 3 \mathrm{H} / \mathrm{HeN}$ and $\mathrm{C} 3 \mathrm{H} / \mathrm{HeJ}$ strains have been employed to define the contribution of TLR4 to dermal carcinogenesis elicited by several environmental chemicals. 2,3,7,8-Tetrachlorodibenzo- $p$-dioxin, polybrominated biphenyls, and mycotoxins have all been reported to be associated with endotoxin hypersensitivity [56-58].

Yusuf et al. [22] compared $\mathrm{C} 3 \mathrm{H} / \mathrm{HeN}$ and $\mathrm{C} 3 \mathrm{H} / \mathrm{HeJ}$ mice for their susceptibility to 2-stage DMBA/TPA skin tumorigenesis. It is important to note that both $\mathrm{C} 3 \mathrm{H} / \mathrm{HeN}$ and $\mathrm{C} 3 \mathrm{H} / \mathrm{HeJ}$ mice required much larger doses of DMBA than other mouse strains. Significantly more carcinogen adducts formed in $\mathrm{C} 3 \mathrm{H} / \mathrm{HeJ}$ mice than in $\mathrm{C} 3 \mathrm{H} / \mathrm{HeN}$ mice. There was no difference in the ornithine decarboxylase activity, indicating that differences in response to DMBA were caused by effects at the initiation stage of carcinogenesis [22]. When the 2 strains were subjected to a DMBA/TPA chemical skin tumorigenesis protocol, $\mathrm{C} 3 \mathrm{H} / \mathrm{HeJ}$ mice were found to produce significantly more skin tumors with a shorter latency period than $\mathrm{C} 3 \mathrm{H} / \mathrm{HeN}$ mice treated in the same manner. Disparities in the capacity of these 2 strains to skin tumor development were due to differences in the type of cell-mediated immune responses to DMBA. After 25 weeks, $\mathrm{C} 3 \mathrm{H} / \mathrm{HeN}$ mice produced greater levels of interferon- $\gamma$, whereas $\mathrm{C} 3 \mathrm{H} / \mathrm{HeJ}$ mice had greater levels of IL-17. From these studies, it was concluded that TLR4 has a protective role against the development of chemically induced mouse skin tumors due to differences in the characteristics of the cell-mediated immune response elicited by carcinogenic PAHs [22]. Similar observations have occurred in a DMBA-induced mammary carcinogenesis model. $\mathrm{C} 3 \mathrm{H} / \mathrm{HeJ}$ mice developed significantly more mammary tumors than $\mathrm{C} 3 \mathrm{H} / \mathrm{HeN}$ mice due to exaggerated IL-17-mediated immunity [59].

\section{Murine Skin Carcinogenesis Models for Regulatory Use}

Many different mouse strains have been used to evaluate the skin carcinogenicity of various xenobiotics and to analyze steps in its pathogenesis. Strains vary in their susceptibility to different chemicals, and thus reliance on a single or inappropriate strain may lead to 
Table 3. Regulatory standards for the classification of a chemical as a skin carcinogen

Evaluation of at least 2 mouse strains

Preliminary 90-day dose finding experiments that include microscopic evaluation of the skin that should be conducted prior to a long-term skin carcinogenesis study

Dermal carcinogenicity experiments conducted in the same mouse strain as the dose finding experiments Studies conducted in male mice

Selection of doses for the dermal carcinogenesis studies that are low enough to avoid ulceration

inaccurate conclusions. For example, problems with genetic drift were noted with the SENCAR mouse, thus limiting its use as a susceptible strain [24,60].

In 1988, an environmental protection agency (EPA) workshop was convened for the purpose of developing guidelines for the assessment of environmental chemicals and toxins through the dermal route. Several criteria were described which are necessary for a chemical to meet the regulatory standards as a potential carcinogen (Table 3). This provides validity criteria and options for those testing a given chemical for carcinogenicity.

Since the 1988 EPA workshop, a number of new mouse models have become available for carcinogenesis experiments. At that time, there were no mouse models for cutaneous BCC; the $\mathrm{Ptch}^{-/}$mouse has been developed for that purpose [61]. These mice have an activating mutation in the sonic hedgehog signal transduction pathway, which is similar to the mutation seen in human BCCs. More recently, by back-crossing heterozygous $\mathrm{Ptch}^{+/-}$mutant mice to SKH-1 hairless mice, it has been possible to generate animals that develop both BCCs and SCCs following exposure to UV radiation [62].

Similarly, although there are a number of animal models for melanoma, most were not available in 1988 and are not amenable to evaluation for melanoma development. At that time, melanoma models were largely restricted to transplantable syngeneic melanoma lines, such as B16, compatible only with C57BL/6 mice [63]. In that model, melanomas are already present, making it impossible to assess earlier steps in melanomagenesis. Transgenic mice with enforced expression of mutant oncogenes have also been generated [64]. These animal models rapidly develop melanomas without first showing evidence of dysplastic nevi (i.e., premalignant precursors of melanoma). Moreover, it is difficult to study immunosurveillance since the genes are expressed in all tissue-specific cells (defined by transgene promoter). Recently, an in vivo model has been created in which mice large numbers of pigmented nevi develop that progress to become invasive melanomas and then metastasize to regional lymph nodes $[65,66]$. The clinical, genetic, and biochemical features closely resemble those that occur in humans.

\section{Acrylates}

Acrylic monomers are made of acrylic acid and consist of esters of variable carbon length [67]. The family of lower alkyl acrylate monomers includes methyl acrylate, ethyl acrylate (EA), n-butyl acrylate, and 2-ethylhexyl acrylate (2-EHA, CAS: 103-11-7). All have a common hydrocarbon backbone and an identical functional group. They are distinguished from each other by differences in their chain length, physicochemical characteristics, and toxicokinetic behavior (Table 4) [68]. Acrylic monomers serve as reactants for polymers and copolymers. Following a curing process, the polymers and copolymers have a number of unique physical and chemical properties including durability, weather resistance, color stability, and high gloss that make them indispensable for numerous applications [69-72].

Of particular interest with respect to skin carcinogenesis is 2-EHA. 2-EHA is an acrylate used as a co-monomer in the production of polymer resins for adhesives, latex paints, cross-

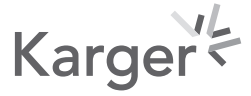


Table 4. Physicochemical and toxicokinetic properties of acrylates

\begin{tabular}{|c|c|c|c|c|}
\hline Property & $\begin{array}{l}\text { Methyl } \\
\text { acrylate }\end{array}$ & $\begin{array}{l}\text { Ethyl } \\
\text { acrylate }\end{array}$ & $\begin{array}{l}\text { n-butyl } \\
\text { acrylate }\end{array}$ & $\begin{array}{l}\text { 2-Ethylhexyl } \\
\text { acrylate }\end{array}$ \\
\hline CASRN & $96-33-3$ & $140-88-5$ & $141-32-2$ & $103-11-7$ \\
\hline Molecular weight, $\mathrm{g} / \mathrm{mol}$ & 86.1 & 100.1 & 128.2 & 184.3 \\
\hline Physical state at $20^{\circ} \mathrm{C}$ and $101.3 \mathrm{kPa}$ & Liquid & Liquid & Liquid & Liquid \\
\hline Freezing point, ${ }^{\circ} \mathrm{C}$ & -76.5 & -71.2 & -64.6 & -90 \\
\hline Boiling point, ${ }^{\circ} \mathrm{C}$ & 80.1 & 99.8 & 147 & 215 \\
\hline Relative density & 0.95 & 0.92 & 0.90 & 0.88 \\
\hline Vapor pressure, $\mathrm{hPa}$ & $90\left(20^{\circ} \mathrm{C}\right)$ & $40\left(21^{\circ} \mathrm{C}\right)$ & $5\left(22^{\circ} \mathrm{C}\right)$ & $0.24\left(25^{\circ} \mathrm{C}\right)$ \\
\hline Water solubility, g/L & $60\left(25^{\circ} \mathrm{C}\right)$ & $20\left(20^{\circ} \mathrm{C}\right)$ & $1.7\left(20^{\circ} \mathrm{C}\right)$ & $0.01\left(25^{\circ} \mathrm{C}\right)$ \\
\hline Partition coefficient n-octanol/water (log value) & 0.74 & 1.18 & 2.38 & 4.00 \\
\hline \multicolumn{5}{|l|}{ In vitro enzymatic half-life degradation, $\mathrm{t}^{1 / 2} \mathrm{~min}$} \\
\hline Rat liver microsomes & 8.2 & 1.9 & 0.8 & 2.3 \\
\hline Blood & 1.5 & 2.3 & 2.3 & 3.9 \\
\hline Mean peptide depletion (DPRA, OECD TG 442c), \% & 93 & 95 & 95.8 & 60.5 \\
\hline Predicted skin absorption, $\%$ & 67.97 & 68.0 & 99.3 & 99.6 \\
\hline
\end{tabular}

CASRN, CAS registry number; DPRA, direct peptide reactivity assay; OECD TG, Organisation for Economic Co-Operation and Development Test Guideline. Source: Suh et al. [68], 2018/Murphy et al. [74], 2018.

linking agents, finishes for textiles and leather, and paper coatings. It is produced, distributed, stored, and consumed in closed systems. 2-EHA exposure may occur in occupational settings where it is produced or used; however, the only exposure that may occur to consumers or construction personnel is trace amounts in the final polymer product [73]. Occupational exposure can occur during maintenance, sampling, or testing by either manual transfer or other procedures [74]. Acrylate exposure in occupational settings is mitigated by the use of personal protective equipment to control dermal or inhalation exposure in industries in which this compound is produced or used $[74,75]$.

\section{In vitro and in vivo Genotoxicity Testing of 2-EHA}

The acrylate monomers have been comprehensively tested with respect to genotoxicity in vitro and in vivo [74] (Table 5). In in vivo genotoxicity tests, the acrylates generally show negative results, whereas in in vitro tests, especially clastogenicity tests in mammalian cells, some positive results have been reported. These in vitro positive results usually occur only at cytotoxic concentrations. Overall, this class of chemicals seems to have no specific genotoxic potential. Bacterial reverse mutation assays (Ames tests) were found to be negative for 2-EHA. Eleven negative studies for lower alkyl acrylate monomers included 2 for 2-EHA [76, 77]. When 2-EHA was tested in vitro for hypoxanthine-guanine phosphoribosyltransferase (HPRT) using Chinese hamster ovary (CHO) cells, no mutagenic effect was obtained [78]. This result was confirmed in a recent Organization for Economic Co-Operation and Development Test Guideline (OECD TG) 476 study using an in vitro HPRT locus gene mutation assay (with CHO cells), with 2-EHA shown to be non-mutagenic [74]. In one study type, the mouse lymphoma assay, positive results were reported indicating a clastogenic effect but only at cytotoxic concentrations $[79,80]$. Mouse lymphoma cells were exposed to concentrations of $20-34 \mu \mathrm{g} / \mathrm{mL}$ for $4 \mathrm{~h}$ without using the S9 mix, which proved to be toxic to cells with $12-27 \%$ relative survival [80]. In in vitro clastogenicity tests, 2-EHA did not show a positive result. Based on experimental limitations, a chromosomal aberration test was judged to be inconclusive; in addition, no clastogenic effect was detected in the parallel-performed micronu- 
Table 5. Genotoxicity and mutagenicity data of 2-ethylhexyl acrylate

\author{
In vitro tests \\ Gene mutation in bacteria \\ Ames test: negative \\ Gene mutation in mammalian cells \\ HPRT: negative \\ MLA (TK): positive at cytotoxic concentrations \\ Cytogenicity \\ Micronucleus test: negative \\ Chromosomal aberration: inconclusive \\ Sister chromatid exchange: negative
}

\author{
In vivo tests \\ Cytogenicity \\ Chromosomal aberration: negative \\ DNA damage assay \\ UDS test: negative
}

HPRT, hypoxanthine-guanine phosphoribosyltransferase; MLA (TK), mouse lymphoma thymidine kinase assay; UDS, unscheduled DNA synthesis. Source: Suh et al. [68], 2018/Murphy et al. [74], 2018.

cleus test [80]. In a recent OECD TG 487 in vitro micronucleus test, 2-EHA was negative, confirming no clastogenic effect $[68,74,78,80]$. In an in vivo study in which mice were treated once or repeatedly with 2-EHA, no clastogenic effect was described [81]. 2-EHA was also tested in rats to evaluate a possible induction of DNA repair in an OECD TG 486 guideline test (UDS test); 2-EHA did not induce DNA damage in this test [82].

\section{Screening and Regulatory Testing of Alkyl Acrylates in Mouse Skin Carcinogenesis Models}

Few studies evaluating the carcinogenic effect of alkyl acrylates in mice have been performed [74]. In one study, experiments were conducted in which undiluted EA, $1 \%$ acrylic acid, and $1 \%$ butyl acrylate were applied to the dorsal skin of $\mathrm{C} 3 \mathrm{H} / \mathrm{HeJ}$ mice 3 times weekly for their lifetime. None of the panels developed skin tumors, although the positive control (3 methylcholanthrene) did [83]. 2-EHA was tested in a screening study in C3H/HeJ mice in which animals were treated with 2-EHA applied to the dorsal skin 3 times weekly throughout their life. Of the compounds tested, 2-EHA was found to produce skin tumors [84]. A second 2-EHA skin carcinogenicity study was published in 1989 [85]. Groups of 80 male C3H/HeJ mice per panel were treated with topical 2 -EHA, $0,29,250,500$, and $1,000 \mathrm{mg} / \mathrm{kg}$ body weight $(0,2.5,21,43.5$, and $86.5 \%$ in acetone, respectively), 3 times per week for 24 weeks. Even at the $2.5 \%$ concentration, significant crusting and scabbing of the skin, equivalent to ulceration, was observed in a significant proportion of the 2-EHA-treated mice. At both the 21 and $86.5 \%$ concentrations, tumors developed. A variety of different skin tumors was identified at the administration site. The skin in general was markedly inflamed, with cytotoxicity and regeneration [85]. These tumors were shown to regress after cessation of 2-EHA exposure, which supports the hypothesis that chronic tissue damage was necessary for the generation and persistence of dermal tumors with this agent. BCCs and melanomas were observed, but their assessment was solely by histological evaluation [85].

Mellert et al. [86] conducted a similar study to that described above but in the NMRI strain (Table 1). The NMRI mouse studies were performed in an attempt to corroborate the 
findings in $\mathrm{C} 3 \mathrm{H} / \mathrm{HeJ}$ mice [85]. In contrast to the findings in the study by Wenzel-Hartung et al. [85], the NMRI strain did not result in 2-EHA-induced skin tumor development. Panels of NMRI mice (80 mice per panel) were treated with 2.5, 21, or $86.5 \%$ 2-EHA 3 times per week for 7 months. At that time, each panel was subdivided into groups A and B. Group A of each panel continued to receive 2-EHA 3 times per week until the termination of the experiment (i.e., 2 years). B groups received no treatment for 2 months and were then treated with TPA 2 times per week for an additional 20 weeks, after which they were observed until the end of the experiment (i.e., 2 years). No tumors developed in NMRI mice treated with 2-EHA throughout the study (including melanomas); only 1 animal per panel in the group treated with 2-EHA and TPA developed squamous papillomas, but in the acetone-treated negative control group, one of the mice also developed a squamous papilloma [86].

EA was not found to develop tumors in $\mathrm{C} 3 \mathrm{H} / \mathrm{HeJ}$ mice whereas 2-EHA did. The reason for this has not been investigated but could be due to differences in the physicochemical properties, like vapor pressure, of the two compounds, differences in their inherent ability to elicit T-cell-mediated host defense mechanisms, or dissimilarities in their proinflammatory proficiencies (Table 4).

While not to deny the value of these reports, it is important to recognize their limitations. (1) Very high doses/concentrations of 2-EHA were employed, i.e., substantially greater than those to which humans are exposed. This monomer is only handled in workplaces under controlled conditions that minimize or eliminate exposure. (2) At all of the doses used, topical application of 2-EHA caused crusting, inflammation, and ulcerations of the skin. (3) C3H/HeJ mice are an imperfect model for cancer assessments because they have deviant innate and adaptive immunity due to an inactivating mutation in the gene that encodes the TLR4. (4) Skin lesions regressed after application of 2-EHA (43\%) was discontinued, calling into question whether they were malignant or merely pseudoepitheliomatous hyperplasia. No tumors could be seen in the low-dose (2.5\%) group when skin irritation occurred only during the initial phases of the experiment. (5) The MMTV status of the $\mathrm{C} 3 \mathrm{H} / \mathrm{HeJ}$ mice was also not stated; if these mice carried the virus, it may have influenced the results of the skin carcinogenesis studies. These observations provide strong evidence that chronic inflammation and immune dysregulation, rather than genotoxic injury, were responsible for the tumors that occurred [86].

The types of tumors that developed in $\mathrm{C} 3 \mathrm{H} / \mathrm{HeJ}$ mice are noteworthy [85]. Premalignant papillomas, SCCs, fibrosarcomas, BCCs, and melanomas were reported. The pathogeneses of these neoplasms are all different, with distinct mutations in each type. This provides additional support for the concept that the effect of 2 -EHA in $\mathrm{C} 3 \mathrm{H} / \mathrm{HeJ}$ mice was caused by chronic inflammation or a deviant immune response. Due to the TLR4 mutation, there is an increase in the number of inflammatory cells and chronic dermal irritation in the skin in $\mathrm{C} 3 \mathrm{H} / \mathrm{HeJ}$ mice $[74,87,88]$. Until recently, there have not been any murine BCC models. The observation that melanomas arose in 2-EHA-treated mice is also surprising since there were no good models of melanomagenesis at the time that the study was conducted [65]. The lack of careful characterization of the pigmented lesions raises the issue of whether they were actually melanomas; the skin pigmentation could have been collections of melanophages that had phagocytosed melanin in the dermis. Current methods that are used to definitively identify melanomas include immunohistochemical and/or mRNA evaluation of lesions for tyrosinase, S100, and melan A as well as examination for compatible genetic mutations [65]. 


\section{Effect of Acrylates on Human Health}

A significant human health hazard property of acrylic monomers is allergic contact dermatitis [89]. The North American Contact Dermatitis Group estimates that contact allergic reactions to acrylates (which includes methacrylates) are common. EA is the 32nd most common cause of dermatitis in the United States and methyl methacrylate is the 44th [89]. Allergic reactions to 2-EHA, on the other hand, occur but are much less frequent. No allergic responses were recorded for 2-EHA in a study that reviewed 10 years of data for patch testing [90], and no cross-reaction to 2-EHA was observed in a cohort of 275 patients with a history of exposure to methacrylate [91]. Exposure in workplace settings can occur during the production of 2-EHA, formulations of preparations containing up to 21\% 2-EHA, use of formulations containing monomeric 2-EHA in the construction industry, and use of dispersions with residual monomeric 2-EHA $(<0.08 \%)$ [92]. Inhalation of 2-EHA vapors can cause irritation in the nose, throat, and lungs. Higher concentrations of 2-EHA can cause drowsiness, dizziness, tiredness, headache, nausea, difficulty in breathing, and convulsions. Exposure to 2 -EHA vapors can cause irritation in eyes accompanied by tears. A liquid form of 2-EHA can cause burning of eyes. Pure liquid or concentrated 2-EHA can cause severe dermal irritation and burns [93].

With respect to human skin carcinogenesis caused by acrylates, there are few studies that have addressed this issue. In one study, 60 individuals from the Czech Republic exposed to acrylic acid, acrylates, and acrylate dispersions and 60 controls were evaluated for genotoxicity [94]. Exposures were assessed by personal passive dosimetry (GC/MS method). Subjects were evaluated annually, at which time they received a general medical examination, routine laboratory studies, as well as serological tests of immunity and tumor markers. Over a period of 8 years, no significant differences in cytogenetic aberrations were observed when both groups were compared. An epidemiological study revealed a relationship between mortality from colon or rectal cancer and exposure to EA and methyl methacrylate, but evidence is conflicting and inconclusive [95]. Specifically, no correlation was observed in cohorts after 1940, but a correlation was described in a cohort between 1933 and 1940. This earlier cohort did not recognize co-exposures to multiple chemicals which occurred (including: lead, ethylene dichloride, and acrylonitrile) while the authors disregarded confounding factors like smoking, alcohol use, and the personal history of inflammatory bowel disease [95]. There are no reports of acrylate exposure in humans causing skin cancer, including 2-EHA. Acrylate and methacrylate polymers are being used in nanomedicine as carriers for anticancer drugs, which provides additional evidence against their carcinogenicity in humans [96-99].

\section{Conclusions}

Acrylates are used as co-monomers in the production of polymers with a broad array of industrial and consumer applications. Proper exposure controls (personal protective equipment and engineering controls) are used to prevent occupational or professional exposure to these agents, which could occur through inhalation or dermal contact. Consumer exposure potential is limited, as only trace residual levels remain in consumer products. There is no evidence from in vitro genotoxicity experiments or human epidemiologic observations that they cause cancer. Although 2-EHA was found to cause skin tumors in $\mathrm{C} 3 \mathrm{H} / \mathrm{HeJ}$ mice, it was only able to do so when applied topically on a chronic basis at exceptionally high doses that caused crusting, ulcerations, and marked inflammation. Moreover, the skin carcinogenic activity of 2-EHA could not be reproduced in the NMRI strain. It is important to 
emphasize that the $\mathrm{C} 3 \mathrm{H} / \mathrm{HeJ}$ mouse model is not an ideal mouse model to investigate carcinogenicity for regulatory purposes as it has dysregulated immune and inflammatory pathways. Specifically, the $\mathrm{C} 3 \mathrm{H} / \mathrm{HeJ}$ strain has a deficiency in TLR4 signaling that impairs its innate and adaptive immune responses. Genotoxicity studies for acrylates including 2-EHA have been negative, suggesting that the findings of skin cancers in $\mathrm{C} 3 \mathrm{H} / \mathrm{HeJ}$ mice were caused by chronic inflammation. In addition, even with those acrylates in which skin tumors occurred, skin carcinogenicity could not be reproduced in a second strain. One of the criteria proposed in the EPA Guidelines in 1988 to categorize a given chemical as carcinogenic was that it produces a carcinogenic effect in at least 2 mouse strains.

\section{Perspectives}

Additional testing following recognized guidelines and more current methods of analysis are needed in order to convincingly demonstrate that topical application of 2-EHA causes BCCs, SCCs, or melanomas. This should include: (1) studies in which topical application of 2 -EHA causes skin cancer in other more traditional strains of mice with an intact immune system; (2) experiments in which $\mathrm{Ptch}^{+/-}$or $\mathrm{Ptch}^{+/-} / \mathrm{SKH}-1$ hairless mice are treated with 2-EHA and other acrylates to assess BCC development; (3) evaluation of skin tumorigenesis according to previously proposed standards in at least 2 strains of mouse [60]; and (4) careful assessment of tumors, employing contemporary techniques that were not present in the 1980s to make sure they are actually the types of tumors that they appear to be on routine histology and that the molecular and genetic changes are relevant to human exposure. In conclusion, to date, the tested alkyl acrylates appear to be non-carcinogenic following dermal application, while a cutaneous carcinogenic effect of 2-EHA has not been convincingly demonstrated. Importantly, the studies that have been done showing skin carcinogenic activity of 2-EHA have questionable relevance to humans.

\section{Conflict of Interest Statement}

This work was funded by the Basic Acrylic Monomer Manufacturers, Inc. The contents of this manuscript reflect the views of the authors.

\section{Funding Sources}

C.A.E. and N.Y. gratefully acknowledge the financial support of the Basic Acrylic Monomer Manufacturers, Inc., for preparation of the manuscript.

\section{Author Contributions}

C.A.E and N.Y met the criteria for authorship. 


\section{References}

1 Lim HW, Collins SA, Resneck JS Jr, Bolognia JL, Hodge JA, Rohrer TA, et al. The burden of skin disease in the United States. J Am Acad Dermatol. 2017 May;76(5):958-972.e2.

2 Rogers HW, Weinstock MA, Feldman SR, Coldiron BM. Incidence Estimate of Nonmelanoma Skin Cancer (Keratinocyte Carcinomas) in the U.S. Population, 2012. JAMA Dermatol. 2015 Oct;151(10):1081-6.

3 Grossman D, Leffell DJ. Squamous Cell Carcinoma. In: Goldsmith LA, Katz SI, Gilchrest B, Paller AS, Leffell DJ, Wolff K, editors. Fitzpatrick's Dermatology in General Medicine. New York: McGraw-Hill; 2012. p. 1283-94.

4 Abel EL, Angel JM, Kiguchi K, DiGiovanni J. Multi-stage chemical carcinogenesis in mouse skin: fundamentals and applications. Nat Protoc. 2009;4(9):1350-62.

5 Camp WL, Turnham JW, Athar M, Elmets CA. New agents for prevention of ultraviolet-induced nonmelanoma skin cancer. Semin Cutan Med Surg. 2011 Mar;30(1):6-13.

6 Elmets CA, Cala CM, Xu H. Photoimmunology [vii.]. Dermatol Clin. 2014 Jul;32(3):277-90.

7 Marks R, Foley P, Goodman G, Hage BH, Selwood TS. Spontaneous remission of solar keratoses: the case for conservative management. Br J Dermatol. 1986 Dec;115(6):649-55.

8 Bouwes Bavinck JN, Vermeer BJ, van der Woude FJ, Vandenbroucke JP, Schreuder GM, Thorogood J, et al. Relation between skin cancer and HLA antigens in renal-transplant recipients. N Engl J Med. 1991 Sep; 325(12):843-8.

9 Hartevelt MM, Bavinck JN, Kootte AM, Vermeer BJ, Vandenbroucke JP. Incidence of skin cancer after renal transplantation in The Netherlands. Transplantation. 1990 Mar;49(3):506-9.

10 Jensen P, Møller B, Hansen S. Skin cancer in kidney and heart transplant recipients and different long-term immunosuppressive therapy regimens. J Am Acad Dermatol. 2000 Feb;42(2 Pt 1):307.

11 Maule M, Scélo G, Pastore G, Brennan P, Hemminki K, Tracey E, et al. Risk of second malignant neoplasms after childhood leukemia and lymphoma: an international study. J Natl Cancer Inst. 2007 May;99(10):790-800.

12 Mellemgaard A, Geisler CH, Storm HH. Risk of kidney cancer and other second solid malignancies in patients with chronic lymphocytic leukemia. Eur J Haematol. 1994 Oct;53(4):218-22.

13 Weimar VM, Ceilley RI, Goeken JA. Cell-mediated immunity in patients with basal and squamous cell skin cancer. J Am Acad Dermatol. 1980 Feb;2(2):143-7.

14 Yoshikawa T, Rae V, Bruins-Slot W, Van den Berg JW, Taylor JR, Streilein JW. Susceptibility to effects of UVB radiation on induction of contact hypersensitivity as a risk factor for skin cancer in humans. J Invest Dermatol. 1990 Nov;95(5):530-6.

15 Kaporis HG, Guttman-Yassky E, Lowes MA, Haider AS, Fuentes-Duculan J, Darabi K, et al. Human basal cell carcinoma is associated with Foxp3+ T cells in a Th2 dominant microenvironment. J Invest Dermatol. 2007 Oct;127(10):2391-8.

16 Zhang S, Fujita H, Mitsui H, Yanofsky VR, Fuentes-Duculan J, Pettersen JS, et al. Increased Tc22 and Treg/CD8 ratio contribute to aggressive growth of transplant associated squamous cell carcinoma. PLoS One. 2013 May; 8(5):e62154.

17 Kripke ML. Antigenicity of murine skin tumors induced by ultraviolet light. J Natl Cancer Inst. 1974 Nov;53(5): 1333-6.

18 Blum HF. Carcinogenesis by Ultraviolet Light. Princeton: Princeton University Press; 1959.

19 Elmets CA, Athar M, Tubesing KA, Rothaupt D, Xu H, Mukhtar H. Susceptibility to the biological effects of polyaromatic hydrocarbons is influenced by genes of the major histocompatibility complex. Proc Natl Acad Sci USA. 1998 Dec;95(25):14915-9.

20 Yusuf N, Nasti TH, Katiyar SK, Jacobs MK, Seibert MD, Ginsburg AC, et al. Antagonistic roles of CD4+ and CD8+ T-cells in 7,12-dimethylbenz(a)anthracene cutaneous carcinogenesis. Cancer Res. 2008 May;68(10):3924-30.

21 Yusuf N, Nasti TH, Ahmad I, Chowdhury S, Mohiuddin H, Xu H, et al. In vivo Suppression of Heat Shock Protein (HSP) 27 and HSP70 Accelerates DMBA-Induced Skin Carcinogenesis by Inducing Antigenic Unresponsiveness to the Initiating Carcinogenic Chemical. J Immunol. 2015 May;194(10):4796-803.

22 Yusuf N, Nasti TH, Long JA, Naseemuddin M, Lucas AP, Xu H, et al. Protective role of toll-like receptor 4 during the initiation stage of cutaneous chemical carcinogenesis. Cancer Res. 2008 Jan;68(2):615-22. Erratum in: Cancer Res. 2008 Mar;68(5):1609.

23 Melicow MM. Percivall Pott (1713-1788): 200th anniversary of first report of occupation-induced cancer scrotum in chimmey sweepers (1775). Urology. 1975 Dec;6(6):745-9.

24 OECD. Guideline for the Testing of Chemicals: Carcinogenicity Studies. Paris: OECD; 2018.

25 Neagu M, Caruntu C, Constantin C, Boda D, Zurac S, Spandidos DA, et al. Chemically induced skin carcinogenesis: updates in experimental models (review). Oncol Rep. 2016 May;35(5):2516-28.

26 Carmona-Mora P, Molina J, Encina CA, Walz K. Mouse models of genomic syndromes as tools for understanding the basis of complex traits: an example with the Smith-Magenis and the Potocki-Lupski syndromes. Curr Genomics. 2009 Jun;10(4):259-68.

27 Chaible LM, Corat MA, Abdelhay E, Dagli ML. Genetically modified animals for use in research and biotechnology. Genet Mol Res. 2010 Jul;9(3):1469-82.

28 Walrath JC, Hawes JJ, Van Dyke T, Reilly KM. Genetically engineered mouse models in cancer research. Adv Cancer Res. 2010;106:113-64.

29 Bassi DE, Klein-Szanto AJ. Carcinogen-induced animal models of head and neck squamous cell carcinoma. Curr Protoc Pharmacol. 2007 Jun; 37(1):14.12.1-19. 
30 Digiovanni J. Modification of multistage skin carcinogenesis in mice. Modification of tumor development in rodents. 33. Ito N and Sugano H. Basel: Karger; 1991. pp. 192-229.

31 Amornphimoltham P, Leelahavanichkul K, Molinolo A, Patel V, Gutkind JS. Inhibition of Mammalian target of rapamycin by rapamycin causes the regression of carcinogen-induced skin tumor lesions. Clin Cancer Res. 2008 Dec;14(24):8094-101.

32 Segrelles C, Lu J, Hammann B, Santos M, Moral M, Cascallana JL, et al. Deregulated activity of Akt in epithelial basal cells induces spontaneous tumors and heightened sensitivity to skin carcinogenesis. Cancer Res. 2007 Nov;67(22):10879-88.

33 Wolf CR, Henderson CJ. Use of transgenic animals in understanding molecular mechanisms of toxicity. J Pharm Pharmacol. 1998 Jun;50(6):567-74.

34 Kemp CJ. Multistep skin cancer in mice as a model to study the evolution of cancer cells. Semin Cancer Biol. 2005 Dec;15(6):460-73.

35 Rundhaug JE, Fischer SM. Molecular mechanisms of mouse skin tumor promotion. Cancers (Basel). 2010;2(2): 436-82.

36 Verma AK, Wheeler DL, Aziz MH, Manoharan H. Protein kinase Cepsilon and development of squamous cell carcinoma, the nonmelanoma human skin cancer. Mol Carcinog. 2006 Jun;45(6):381-8.

37 Chen J, Roop DR. Genetically engineered mouse models for skin research: taking the next step. J Dermatol Sci. 2008 Oct;52(1):1-12.

38 Lennon-Pierce M, Eppig JT. Mouse Inbred Strains. In: Delves PJ, editor. Encyclopedia of Immunology. 2nd ed. Oxford: Elsevier; 1998. pp. 1762-70.

39 Rivina L, Schiestl R. Mouse models of radiation-induced cancers. Adv Genet. 2013;84:83-122.

40 Welsh J. Chapter 35: Modeling Breast Cancer in Animals-Considerations for Prevention and Treatment Studies. In: Conn PM, editor. Animal Models for the Study of Human Disease. 2nd ed. New York: Academic Press; 2017. p. 925-48.

41 Chang B, Hawes NL, Pardue MT, German AM, Hurd RE, Davisson MT, et al. Two mouse retinal degenerations caused by missense mutations in the $\beta$-subunit of rod cGMP phosphodiesterase gene. Vision Res. 2007 Mar; 47(5):624-33.

42 Burns E, Schenken J. Spontaneous Primary Hepatomas in Mice of Strain C3H. II. The Influence of Breeding on Their Incidence. Cancer Res. 1943;3:697-701.

43 Paigen B, Morrow A, Brandon C, Mitchell D, Holmes P. Variation in susceptibility to atherosclerosis among inbred strains of mice. Atherosclerosis. 1985 Oct;57(1):65-73.

44 Janvier Labs. 2020. https://www.janvier-labs.com/en/fiche_produit/c3h_mouse/.

45 O'Brien AD, Rosenstreich DL, Scher I, Campbell GH, MacDermott RP, Formal SB. Genetic control of susceptibility to Salmonella typhimurium in mice: role of the LPS gene. J Immunol. 1980 Jan;124(1):20-4.

46 Byrd-Leifer CA, Block EF, Takeda K, Akira S, Ding A. The role of MyD88 and TLR4 in the LPS-mimetic activity of Taxol. Eur J Immunol. 2001 Aug;31(8):2448-57.

47 Okamura Y, Watari M, Jerud ES, Young DW, Ishizaka ST, Rose J, et al. The extra domain A of fibronectin activates Toll-like receptor 4. J Biol Chem. 2001 Mar;276(13):10229-33.

48 Termeer C, Benedix F, Sleeman J, Fieber C, Voith U, Ahrens T, et al. Oligosaccharides of Hyaluronan activate dendritic cells via toll-like receptor 4. J Exp Med. 2002 Jan;195(1):99-111.

49 Ohashi K, Burkart V, Flohé S, Kolb H. Cutting edge: heat shock protein 60 is a putative endogenous ligand of the toll-like receptor-4 complex. J Immunol. 2000 Jan;164(2):558-61.

50 Barber SA, Perera PY, Vogel SN. Defective ceramide response in C3H/HeJ (Lpsd) macrophages. J Immunol. 1995 Sep;155(5):2303-5.

51 Ching LM, Baguley BC. Hyporesponsiveness of macrophages from $\mathrm{C} 3 \mathrm{H} / \mathrm{HeJ}$ (endotoxin-resistant) mice to the antitumour agent flavone acetic acid (NSC 347512). Eur J Cancer Clin Oncol. 1989 Oct;25(10):1513-5.

52 McCuskey RS, Urbaschek R, McCuskey PA, Sacco N, Stauber WT, Pinkstaff CA, et al. Deficient Kupffer cell phagocytosis and lysosomal enzymes in the endotoxin-low-responsive C3H/HeJ mouse. J Leukoc Biol. 1984 Nov;36(5):591-600.

53 Jordan WP Jr. Cross-sensitization patterns in acrylate allergies. Contact Dermat. 1975;1(1):13-5.

54 Nway NC, Fujitani Y, Hirano S, Mar O, Win-Shwe TT. Role of TLR4 in olfactory-based spatial learning activity of neonatal mice after developmental exposure to diesel exhaust origin secondary organic aerosol. Neurotoxicology. 2017 Dec;63:155-65.

55 Schwartz DA. The role of TLR4 in endotoxin responsiveness in humans. J Endotoxin Res. 2001;7(5):389-93.

56 Clark GC, Taylor MJ, Tritscher AM, Lucier GW. Tumor necrosis factor involvement in 2,3,7,8-tetrachlorodibenzo-p-dioxin-mediated endotoxin hypersensitivity in C57BL/6J mice congenic at the Ah locus. Toxicol Appl Pharmacol. 1991 Dec;111(3):422-31.

57 Luster MI, Boorman GA, Dean JH, Harris MW, Luebke RW, Padarathsingh ML, et al. Examination of bone marrow, immunologic parameters and host susceptibility following pre- and postnatal exposure to 2,3,7,8-tetrachlorodibenzo-p-dioxin (TCDD). Int J Immunopharmacol. 1980;2(4):301-10.

58 Taylor MJ, Lafarge-Frayssinet C, Luster MI, Frayssinet C. Increased endotoxin sensitivity following T-2 toxin treatment is associated with increased absorption of endotoxin. Toxicol Appl Pharmacol. 1991 Jun;109(1): 51-9.

59 Naseemuddin M, Iqbal A, Nasti TH, Ghandhi JL, Kapadia AD, Yusuf N. Cell mediated immune responses through TLR4 prevents DMBA-induced mammary carcinogenesis in mice. Int J Cancer. 2012 Feb;130(4):765-74. 
60 Summary of the second EPA workshop on carcinogenesis bioassay via the dermal route. May 18-19, 1988. Research Triangle Park, NC. EPA560/6-89-003.

61 Aszterbaum M, Epstein J, Oro A, Douglas V, LeBoit PE, Scott MP, et al. Ultraviolet and ionizing radiation enhance the growth of BCCs and trichoblastomas in patched heterozygous knockout mice. Nat Med. 1999 Nov;5(11): 1285-91.

62 Chaudhary SC, Tang X, Arumugam A, Li C, Srivastava RK, Weng Z, et al. Shh and p50/Bcl3 signaling crosstalk drives pathogenesis of BCCs in Gorlin syndrome. Oncotarget. 2015 Nov;6(34):36789-814.

63 Overwijk WW, Restifo NP. B16 as a mouse model for human melanoma. Curr Protoc Immunol. 2001 May; Chapter 20:Unit 20.1.

64 Kuzu OF, Nguyen FD, Noory MA, Sharma A. Current State of Animal (Mouse) Modeling in Melanoma Research. Cancer Growth Metastasis. 2015 Oct; 8 Suppl 1:81-94.

65 Nasti TH, Cochran JB, Tsuruta Y, Yusuf N, McKay KM, Athar M, et al. A murine model for the development of melanocytic nevi and their progression to melanoma. Mol Carcinog. 2016 May;55(5):646-58.

66 Nasti TH, Cochran JB, Vachhani RV, McKay K, Tsuruta Y, Athar M, et al. IL-23 Inhibits Melanoma Development by Augmenting DNA Repair and Modulating T Cell Subpopulations. J Immunol. 2017 Jan;198(2):950-61.

67 Autian J. Structure-toxicity relationships of acrylic monomers. Environ Health Perspect. 1975 Jun;11:141-52.

68 Suh M, Proctor D, Chappell G, Rager J, Thompson C, Borghoff S, et al. A review of the genotoxic, mutagenic, and carcinogenic potentials of several lower acrylates. Toxicology. 2018 Jun;402-403:50-67.

69 IARC Monographs on the Evaluation of the Carcinogenic Risk of Chemicals to Humans. Vol. 39. Lyon: World Health Organization International Agency for Research on Cancer; 1986.

70 IARC Monographs on the Evaluation of Carcinogenic Risk to Humans. Some Industrial Chemicals. Vol. 60. France: World Health Organization International Agency for Research on Cancer Lyon; 1994.

71 IARC Monographs on the Evaluation of Carcinogenic Risk to Humans. Re-evaluation of Some Organic Chemicals, Hydrazine, and Hydrogen Peroxide. Vol. 71. France: World Health Organization International Agency for Research on Cancer Lyon; 1999.

72 Zondlo Fiume M. Final report on the safety assessment of Acrylates Copolymer and 33 related cosmetic ingredients. Int J Toxicol. 2002;21(3_suppl Suppl 3):1-50.

73 BAMM. Global Product Summary: 2-Ethylhexyl Acrylate. 2014. Available from: http://www.bamm.net/ethylhexyl-acrylate-eha/.

74 Murphy S, Ellis-Hutchings R, Finch L, Welz S, Wiench K. In vitro genotoxicity studies: n-butyl acrylate L5178Y mouse lymphoma (TK+/- locus assay), 2-ethylhexyl acrylate gene mutation assay in Chinese hamster V79 cells, and 2-ethylhexyl acrylate micronucleus test in human lymphocytes. Data Brief. 2018 Jun;20:316-25.

75 NIOSH; National Occupational Exposure Survey (NOES) (1983).

76 National Toxicology Program (NTP). Salmonella: Study Summary. Available from: http://ntp.niehs.nih.gov/. Study ID: 326789. Research Triangle Park, NC: Testing Laboratory: National Institute of Environmental Health Sciences (NIEHS); 1984.

77 Zeiger E, Haworth S, Mortelmans K, Speck W. Mutagenicity testing of di(2-ethylhexyl)phthalate and related chemicals in Salmonella. Environ Mutagen. 1985;7(2):213-32.

78 Moore MM, Parker L, Huston J, Harrington-Brock K, Dearfield KL. Comparison of mutagenicity results for nine compounds evaluated at the hgprt locus in the standard and suspension CHO assays. Mutagenesis. 1991 Jan; 6(1):77-85.

79 Cifone M, Myhr BC. Mutagenicity evaluation of 2-ethylhexyl acrylate in the mouse lymphoma forward mutation assay. Report 81RC-152. Toxicology Department, Rohm \& Haas Company: Spring House, Pennsylvania; 1984.

80 Dearfield KL, Millis CS, Harrington-Brock K, Doerr CL, Moore MM. Analysis of the genotoxicity of nine acrylate/ methacrylate compounds in L5178Y mouse lymphoma cells. Mutagenesis. 1989 Sep;4(5):381-93.

81 Sames JL, McLeod PL, McCarthy KL. 2-Ethylhexyl acrylate in vivo cytogenetic study in mice. Report Number 82 R-085. Toxicology Department, Rohm \& Haas Company: Spring House, Pennsylvania; 1984.

82 Engelhardt G. 2-Ethylhexyl Acrylate. In vivo Unscheduled DNA Synthesis (UDS) Assay with 2-Ethylhexyl Acrylate in Rat Hepatocytes Single Oral Administration. Experimental Toxicology and Ecology (Germany). 2002.

83 DePass LR, Fowler EH, Meckley DR, Weil CS. Dermal oncogenicity bioassays of acrylic acid, ethyl acrylate, and butyl acrylate. J Toxicol Environ Health. 1984;14(2-3):115-20.

84 Gordon SC, Zimmerman DD, Griffith FD. Acute toxicity, genotoxicity, and dermal carcinogenicity assessment of isooctyl acrylate. J Toxicol Environ Health. 1991 Nov;34(3):297-308.

85 DePass LR, Maronpot RR, Weil CS, Wilt F. Dermal oncogenicity bioassays of monofunctional and multifunctional acrylates and acrylate-based oligomers. J Toxicol Environ Health. 1985;16(1):55-60.

86 Wenzel-Hartung RP, Brune H, Klimisch HJ. Dermal oncogenicity study of 2-ethylhexyl acrylate by epicutaneous application in male C3H/HeJ mice. J Cancer Res Clin Oncol. 1989;115(6):543-9.

87 Mellert W, Kühborth B, Gembardt C, Munk R. 2-year carcinogenicity study in the male NMRI mouse with 2-ethylhexyl acrylate by epicutaneous administration. Food Chem Toxicol. 1994 Mar;32(3):233-7.

88 Chen L, Guo S, Ranzer MJ, DiPietro LA. Toll-like receptor 4 has an essential role in early skin wound healing. J Invest Dermatol. 2013 Jan;133(1):258-67.

89 Mittal M, Siddiqui MR, Tran K, Reddy SP, Malik AB. Reactive oxygen species in inflammation and tissue injury. Antioxid Redox Signal. 2014 Mar;20(7):1126-67.

90 DeKoven JG, Warshaw EM, Zug KA, Maibach HI, Belsito DV, Sasseville D, et al. North American Contact Dermatitis Group Patch Test Results: 2015-2016. Dermatitis. 2018 Nov/Dec;29(6):297-309. 
91 Bingham E, Cohrssen B, Powell CH. Patti's Toxicology. Vo. 1-9. 5th ed. New York: Wiley; 2001. p. V6 599.

92 Kanerva L, Jolanki R, Estlander T. 10 years of patch testing with the (meth)acrylate series. Contact Dermat. 1997 Dec;37(6):255-8.

93 ECHA. 2-ethylhexyl acrylate. 2005. [ Accessed 2020, Mar 03]. Available from: https://echa.europa.eu/documents/10162/dae69c42-55ff-4962-9afd-2b65ed7794e1.

94 OSHA. 2010. https://www.osha.gov/dts/sltc/methods/partial/pv2026/2026.html. Accessed on Mar 03, 2020.

95 Tucek M, Tenglerova J, Kollarova B, Kvasnickova M, Maxa K, Mohyluk I, et al. Effect of acrylate chemistry on human health. Int Arch Occup Environ Health. 2002 Oct; 75 Suppl:S67-72.

96 Walker AM, Cohen AJ, Loughlin JE, Rothman KJ, DeFonso LR. Mortality from cancer of the colon or rectum among workers exposed to ethyl acrylate and methyl methacrylate. Scand J Work Environ Health. 1991 Feb; 17(1):7-19.

97 Sahu P, Solanki P, Mitra S. Curcuminoid-loaded poly(methyl methacrylate) nanoparticles for cancer therapy. Int J Nanomed. 2018;13(T-NANO 2014 Abstracts):101-5.

98 Abbad S, Wang C, Waddad AY, Lv H, Zhou J. Preparation, in vitro and in vivo evaluation of polymeric nanoparticles based on hyaluronic acid-poly(butyl cyanoacrylate) and D-alpha-tocopheryl polyethylene glycol 1000 succinate for tumor-targeted delivery of morin hydrate. Int J Nanomed. 2015 Jan;10:305-20.

99 Ghanem GE, Joubran C, Arnould R, Lejeune F, Fruhling J. Labelled polycyanoacrylate nanoparticles for human in vivo use. Appl Radiat Isot. 1993 Sep;44(9):1219-24. 